\title{
The Effects of Erythropoietin Dose Titration during High-Fat Diet-Induced Obesity
}

\author{
Amanda Foskett, Mawadda Alnaeeli, Li Wang, Ruifeng Teng, and Constance T. Noguchi \\ Molecular Medicine Branch, National Institute of Diabetes and Digestive and Kidney Diseases, National Institutes of Health, \\ Bethesda, MD 20892, USA \\ Correspondence should be addressed to Constance T. Noguchi, cnoguchi@helix.nih.gov
}

Received 16 September 2010; Revised 24 January 2011; Accepted 3 February 2011

Academic Editor: Oreste Gualillo

Copyright ( $(2011$ Amanda Foskett et al. This is an open access article distributed under the Creative Commons Attribution License, which permits unrestricted use, distribution, and reproduction in any medium, provided the original work is properly cited.

Erythropoietin (Epo) is a pleotropic cytokine with several nonhematopoietic tissue effects. High-dose Epo treatment-mediated effects on body weight, fat mass and glucose tolerance have recently been reported, thus extending its pleotropic effects to fat and glucose metabolism. However, the exact dose range of Epo treatment required for such effects remains unidentified to date. We investigated Epo dosage effect (up to $1000 \mathrm{U} / \mathrm{kg}$ ) on hematocrit, body weight, body composition, glucose metabolism, food intake, and physical activity, during high-fat diet-induced obesity. We report that Epo doses (1000, 600, 300, and $150 \mathrm{U} / \mathrm{kg})$ significantly reduced body weight gain and fat mass, while, only Epo doses of $300 \mathrm{U} / \mathrm{kg}$ and higher significantly affected glucose tolerance. None of the tested Epo doses showed any detectable effects on food intake, and only $1000 \mathrm{U} / \mathrm{kg}$ dose significantly increased physical activity, suggesting that these parameters may only be partially responsible for the metabolic effects of Epo treatment.

\section{Introduction}

It is estimated that, worldwide, there are approximately one billion overweight and obese people, conditions associated with the metabolic syndrome and increased morbidity, mortality and economic costs $[1,2]$. The metabolic syndrome is a constellation of disorders that include atherogenic dyslipidemia and blood pressure elevation as well as impaired glucose metabolism and insulin resistance that are believed to precede the development of type 2 diabetes [2-5]. Considering the impact of obesity and type 2 diabetes on the health and well-being of the human population, identifying molecular regulators of body weight, fat mass, and glucose metabolism becomes a necessary step toward a better understanding of the underlying mechanisms of such conditions and devising novel therapeutic approaches.

Erythropoietin (Epo), discovered for its indispensable role during erythropoiesis, is a glycoprotein hormone clinically used for the treatment of anemia, mostly in chronic kidney disease $[6,7]$. Epo levels become elevated during hypoxia in response to the activation of hypoxia-inducible factor (HIF) pathway [8-10]. It is produced in the fetal liver and adult kidney, and signals via its receptor (EpoR), a member of the cytokine receptor I superfamily [11]. Considering that EpoR expression has been detected in nonerythroid cells including endothelial cells, epicardium, and brain neuroepithelium [12-14], it is not surprising that Epo treatment can exert several nonhematopoietic effects, among which, its tissue protective effects in heart and brain injuries have been well documented [15-17].

Recent studies implicate Epo signaling in the regulation of body weight, fat mass, and glucose metabolism [18, 19]. For instance, overexpression of Epo in mouse skeletal muscle resulted in reduced body weight and adipose tissue mass and the normalization of insulin levels and glucose tolerance in high fat-fed mice [18]. Similarly, an Epo expressing transgene in mice improved glucose tolerance and insulin sensitivity [19]. Collectively, these observations strongly suggest that the nonhematopoietic effects of Epo may extend to encompass the regulation of fat and glucose metabolism, thereby implicating its signaling as a regulator of glucose tolerance and possibly insulin sensitivity.

To date, the exact dose range of exogenous Epo treatment required for the induction of improved and/or optimal 
metabolic parameters, namely, reduced body weight gain, decreased fat mass accumulation, and higher glucose tolerance remains unidentified. Moreover, it is still unknown whether decreased food intake, increased physical activity, and/or increased hematocrit are entirely responsible for such effects of Epo treatment. Prompted by the aforementioned questions, we investigated the effects of titrated Epo doses $(1000,600,300,150,75$, and $0 \mathrm{U} / \mathrm{kg})$ on hematocrit, body weight gain, body composition, glucose metabolism, food intake and physical activity during high-fat diet-induced obesity. As expected, hematocrit appeared to be Epo dose dependent. To our surprise, high (1000 U/kg), medium (600 and $300 \mathrm{U} / \mathrm{kg}$ ), and low (only $150 \mathrm{U} / \mathrm{kg}$ ) Epo doses significantly reduced body weight gain and fat mass. This reduction in body weight gain and fat mass was not associated with decreased food intake for any of the tested Epo doses and associated with increased physical activity only for $1000 \mathrm{U} / \mathrm{kg}$ group. Most interestingly, high and medium Epo doses $(1000,600$, and $300 \mathrm{U} / \mathrm{kg})$ resulted in significantly increased glucose tolerance in association with a dose-dependent decrease in fasting blood glucose levels, meanwhile, with the exception of $75 \mathrm{U} / \mathrm{kg}$, all other Epo doses (150, 300, 600, and $1000 \mathrm{U} / \mathrm{kg}$ ) resulted in a significant reduction of serum insulin levels. Collectively, our findings show, for the first time, that medium dose of Epo (600 and $300 \mathrm{U} / \mathrm{kg}$ ) can regulate body weight, fat mass, and glucose metabolism with no detectable changes in food intake or physical activity, thereby suggesting the involvement of other pathways in the regulation of Epo-mediated metabolic effects. However, it remains unknown whether decreased food intake and/or increased physical activity are entirely responsible for such effects of Epo treatment, perhaps due to subtle changes at levels below the detection threshold.

\section{Materials and Methods}

2.1. Animals and Reagents. 5-6-week-old male C57BL/6 mice (Fredrick, MD) were housed under specific pathogen-free conditions in the Animal Facility of the National Institute for Diabetes, Digestive and Kidney Diseases, Bethesda, MD. All animal protocols were conducted under the NIH guidelines and approved by the institute's Animal Care and Use Committee. Mice were maintained in a thermo-stated environment under a 12-hour light/dark cycle with free access to food and drinking water. Mice were fed highfat diet containing $60 \mathrm{kcal} \%$ fat (high fat, $5240 \mathrm{kcal} / \mathrm{kg}$, $34.9 \%$ crude fat) (Research Diets, Inc., New Brunswick, NJ) and separated into different groups based on Epo dose ( $n=8$ mice/group). Recombinant human Epoetin alpha (Epogen) (Amgen, Thousand Oaks, CA) was administered subcutaneously every other day using the following doses: $1000,600,300,150$, and $75 \mathrm{U} / \mathrm{kg}$ for 5 weeks, with saline only injected mice as sham controls. In addition, mice fed lowfat diet containing $10 \mathrm{kcal} \%$ fat and injected with saline only were used as normal diet controls.

2.2. Hematocrit Measurements. At the end of the study (i.e., Week 5), hematocrit was measured for all mice. Briefly, blood was collected from the tail using heparin coated capillary tubes which were then centrifuged and used to measure hematocrit with VIN microhematocrit capillary tube reader (Veterinary Information Network Bookstore; Davis, CA).

2.3. Body Weight and Composition Measurements. To assess the effect of Epo treatment on body weight gain and body composition, mice in all groups were weighed weekly, while body composition analysis was performed at the end of the study at week 5 using EchoMRI-100 system (Echo Medical Systems, Houston, TX). The changes in body weight are expressed as body weight gain (g), and changes in body composition expressed as fat and lean mass (g) were calculated using final measurements (week 5) compared to the initial measurements (Day 0) prior to the study onset.

2.4. Glucose Tolerance Test. At week 5, all mice were fasted for 16 hours and challenged with an intraperitoneal load of glucose $(2 \mathrm{~g} / \mathrm{kg})$. Blood glucose of conscious mice was measured at $0,15,30,60,90$, and 120 minutes after glucose administration using code 7 AlphaTRAK glucometer (Abbott Animal Health, Abbott Park, Illinois). Basal blood glucose readings (i.e., at time 0) are fasting blood glucose measurements.

2.5. Serum Insulin Measurements. Blood was collected at week 5 before fasting, and serum insulin was measured using Sensitive Rat Insulin Radioimmunoassay (RIA) Kit (Millipore, St. Charles, Missouri).

2.6. Food Intake Measurements. To assess the effect of Epo treatment on food intake, mice ( $n=6$ /group) were first adapted to individual caging (one mouse/cage) for 1 week, after which were each given $100 \mathrm{~g}$ of food pellets every week. Food intake for each mouse per group was determined by measuring the weight of remaining food pellets every $48 \mathrm{hrs}$.

2.7. Physical Activity Measurements. To assess the effect of Epo treatment on physical activity, total activity of each mouse ( $n=6$ /group) as measured by beam breaks per minute and locomotor activity as measured by total movement episodes per minute (episodes are separated by a rest period of at least 1 second) were determined at the end of the study period (i.e., week 5) by employing AccuScan Instruments Inc manufactured machine and the operating software Fusion 2.2.

2.8. Statistical Analysis. Results are expressed as the mean \pm SEM. ANOVA single-factor test was used for statistical analyses during intergroup comparisons. Values of $P \leq .05$ were considered statistically significant.

\section{Results}

3.1. Epo Treatment and Hematocrit. The most pronounced and commonly characterized effect of exogenous Epo treatment is the resulting elevated hematocrit. As expected, we found that the measured increase in hematocrit directly reflected Epo dosage after 5 weeks of subcutaneous injections (Figure 1). There was a statistically significant difference 


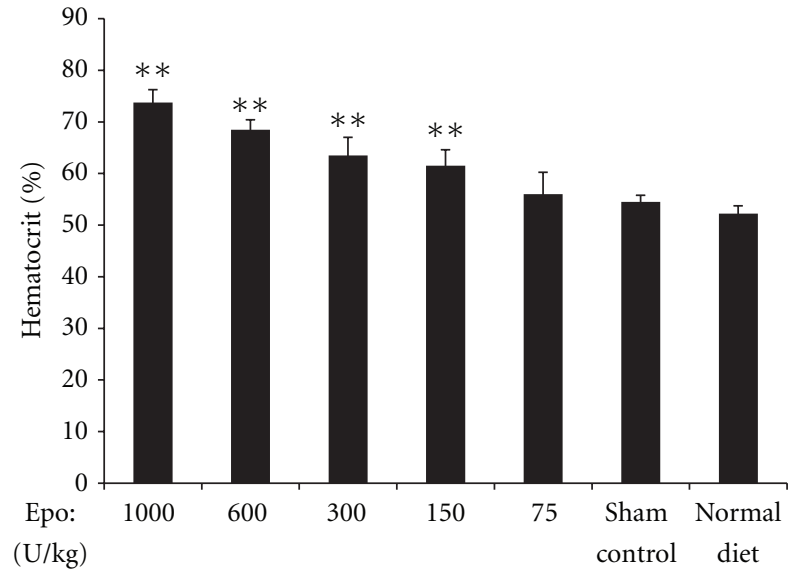

Figure 1: Hematocrit increase is directly reflective of Epo dose treatment. C57BL/6 male mice ( $6 \mathrm{wks}$ of age) were put on $60 \%$ high fat diet and received exogenous Epo treatment of the following doses $(1000,600,300,150$, and $75 \mathrm{U} / \mathrm{kg})$ injected subcutaneously, three times a week; high-fat diet and control diet fed mice injected with saline only were used as sham and normal diet controls, respectively ( $n=8 \mathrm{mice} /$ group). At the end of the study (i.e., week 5), hematocrit was measured for all mice, and the results are expressed as the mean of final \% hematocrit \pm SEM. ANOVA single factor test was used for statistical analysis; values of $P \leq .05$ were considered statistically significant.

in hematocrit levels of $1000,600,300$, and $150 \mathrm{U} / \mathrm{kg}$ Epo treatments which were $73.8 \%, 68.5 \%, 63.5 \%$, and $61.5 \%$, respectively, when compared to sham control $54.5 \%$ (Figure 1); meanwhile, there was no difference between the hematocrit levels of $75 \mathrm{U} / \mathrm{kg}$ Epo-treated group and the sham control which were $56 \%$ versus $54.5 \%$, respectively (Figure 1). Therefore, Epo treatment dose ranges were designated as follows: $1000 \mathrm{U} / \mathrm{kg}$ as high, 600 and $300 \mathrm{U} / \mathrm{kg}$ as medium, and 150 and $75 \mathrm{U} / \mathrm{kg}$ as low Epo doses.

\subsection{High, Medium, and Low Epo Dose Treatments Reduced} Body Weight Gain and Fat Mass. To identify Epo dose range required for reducing body weight gain and fat mass accumulation, we investigated the effects of titrated Epo doses $(1000,600,300,150$, and $75 \mathrm{U} / \mathrm{kg})$ on body weight gain and body composition (i.e., fat versus lean mass) during high-fat diet-induced obesity. C57BL/6 male mice ( 6 wks of age; $n=8$ mice/group) were put on $60 \%$ high fat diet and received exogenous Epo treatment, injected subcutaneously, three times a week. At week 5, body weight gain and composition were determined for all groups and compared to lean and overweight mice injected with saline only as sham and normal diet controls, respectively. Treatment of mice with high dose Epo $(1000 \mathrm{U} / \mathrm{kg})$ resulted in significant reduction in body weight gain $4.78 \pm 0.352 \mathrm{~g}$ when compared to saline-treated controls (i.e., sham control) $9.44 \pm 1.09 \mathrm{~g}$ (Figure 2(a); $P=.001)$. The reduced weight gain observed in mice on 600 and $300 \mathrm{U} / \mathrm{kg}$ Epo was $(5.21 \pm 1.05 \mathrm{~g}$ and $5.18 \pm 0.356 \mathrm{~g}$, resp.) (Figure $2(\mathrm{a}) ; P=.02$ and.01). Meanwhile, of those on lower dose Epo (150 and $75 \mathrm{U} / \mathrm{kg}$ ), only the $150 \mathrm{U} / \mathrm{kg}$ group showed significant difference in body weight gain $(5.4 \pm 0.285 \mathrm{~g})$ when compared to sham controls (Figure 2(a); $P=.01$ ). As expected, none of the Epo dose treatments used caused any detectable changes in lean body mass during body composition analysis (Figure 2(b)).

Overall, the effect of high $(1000 \mathrm{U} / \mathrm{kg})$, medium $(600$ and $300 \mathrm{U} / \mathrm{kg}$ ), and low (only $150 \mathrm{U} / \mathrm{kg}$ ) Epo doses on the reduction of body weight gain was statistically significant, compared with no Epo Sham control (Figure 2(a)). Similarly, when body composition analysis was performed in comparison to sham control, we found doses that reduced body weight gain, to also cause fat mass reduction (Figure 2(c)). Interestingly, $300 \mathrm{U} / \mathrm{kg}$ Epo treatment resulted in a tendency toward lower fat mass accumulation than higher Epo doses of $600 \mathrm{U} / \mathrm{kg}$ and $1000 \mathrm{U} / \mathrm{kg}$; however, this difference was not found to be statistically significant (Figure 2(c)). Thus, not only high $(1000 \mathrm{U} / \mathrm{kg}$ ) but also medium (600 and $300 \mathrm{U} / \mathrm{kg}$ ) and low (150 U/kg) Epo doses can also regulate body weight and fat mass.

3.3. Epo Treatment and Glucose Metabolism. Glucose tolerance is an indirect indicator for insulin sensitivity and healthy pancreatic islets $\beta$-cell response. As previously mentioned, recently reported evidence using high-dose Epo treatment and constitutive overexpression systems implicates Epo in the regulation of blood glucose $[18,19]$. Thus, to assess the effects of Epo doses (1000, 600, 300, 150, and $75 \mathrm{U} / \mathrm{kg}$ ) on glucose tolerance during obesity, C57BL/6 male mice ( 6 wks of age; $n=8 /$ group) were put on $60 \%$ highfat diet and injected subcutaneously with the indicated doses of exogenous Epo, three times a week for 5 weeks. At the end of the study (i.e., week 5), glucose tolerance test (GTT) was performed for all groups in comparison to lean and overweight mice that received saline injections as controls. As expected, mice treated with medium and high Epo doses of 300,600 , and $1000 \mathrm{U} / \mathrm{kg}$ showed significantly higher glucose tolerance than no Epo sham control (Figure 3(a); $P=.002$ ). Consistent with the observed effects on body weight gain and fat mass, Epo dose $(75 \mathrm{U} / \mathrm{kg})$ did not show any difference in glucose tolerance compared to sham controls (Figure 3(a)). In contrast, despite the obvious effects of $150 \mathrm{U} / \mathrm{kg}$ Epo dose on body weight gain and fat mass reduction (Figures 2 (a) and 2(c)), this Epo dose caused no detectable change in glucose tolerance compared to sham controls (Figure 3(a)).

To gain more insight into the observed differential effects for medium and high versus low Epo doses on glucose tolerance (Figure 3(a)), we compared the levels of fasting blood glucose and nonfasting serum insulin of all groups to sham control. We observed an inverse correlation between medium and high Epo doses (300, 600, and $1000 \mathrm{U} / \mathrm{kg}$ ) and fasting blood glucose levels, which was found to be dose dependent, and significantly different from that of the sham control (Figure 3(b); $P=.04, .03$ and .01, resp.). Meanwhile, although treatment with low Epo doses (75 and $150 \mathrm{U} / \mathrm{kg}$ ) did not cause significant reduction in fasting blood glucose, we observed a tendency toward a similar trend between Epo dose and blood glucose (Figure 3(b)). Interestingly, Epo treatment with all doses tested, with the exception of $75 \mathrm{U} / \mathrm{kg}$, resulted in significant reduction of serum insulin levels (Figure 3(c)). These findings collectively 


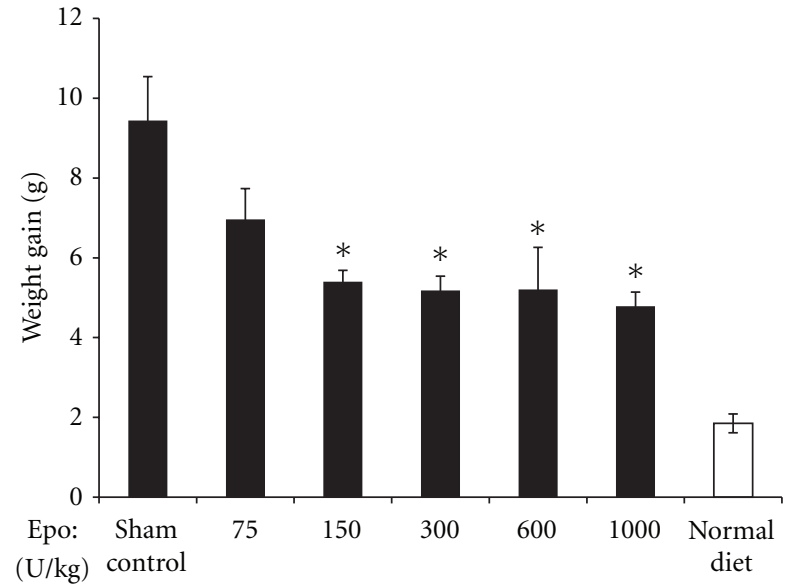

(a)

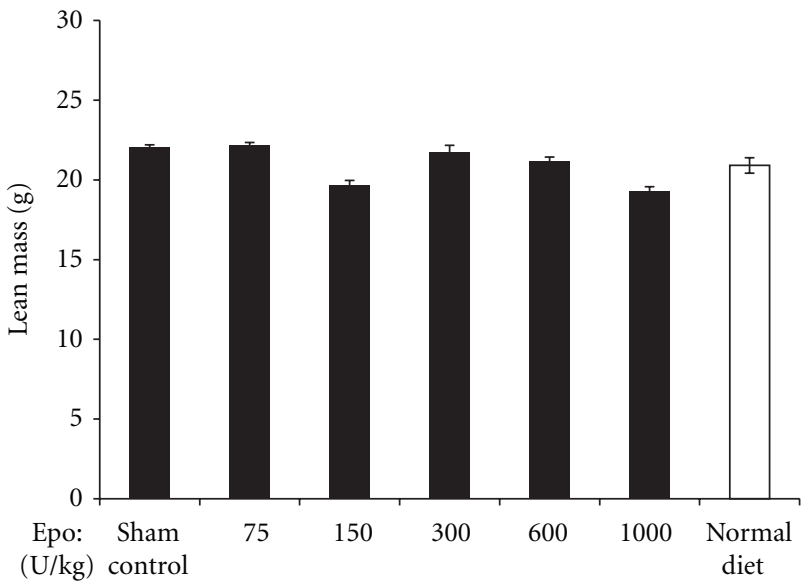

(b)

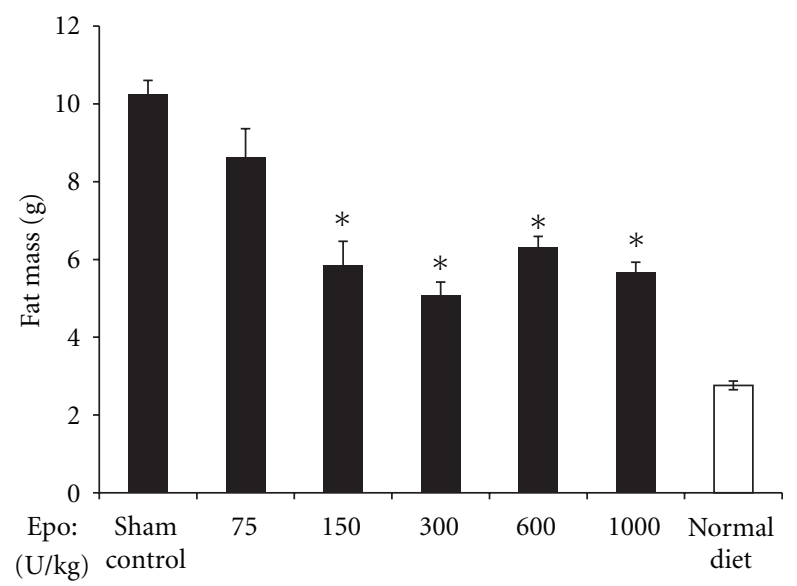

(c)

Figure 2: Epo treatment and body weight gain and composition. C57BL/6 male mice (6 wks of age) were put on $60 \%$ high fat diet and received exogenous Epo treatment of the following doses $(1000,600,300,150$, and $75 \mathrm{U} / \mathrm{kg})$ injected subcutaneously, three times a week ( $n=8$ mice/group). At week 5, body weight gain (a) and body composition; lean mass (b) and fat mass (c) were determined for all groups and compared to lean and overweight mice injected with saline only as sham and normal diet controls, respectively. Results are expressed as the mean \pm SEM. ANOVA single-factor test was used for statistical analysis; values of $P \leq .05$ were considered statistically significant.

indicate that the involvement of Epo treatment in the regulation of glucose metabolism is not restricted to its high dose range.

\subsection{Effects of Epo Treatment on Food Intake and Physical} Activity. Since changes in food intake and physical activity greatly influence body weight and composition, we assessed whether or not Epo doses found to significantly reduce body weight gain and fat mass, namely, (150, 300, 600, and $1000 \mathrm{U} / \mathrm{kg}$; Figures 2(a) and 2(c)) can change these parameters. Comparing all groups to each other and to sham controls, we found no detectable change in food intake (Figure 4(a)). Results from activity measurements as determined by beam breaks per minute showed significantly increased total activity to be exclusive for the $1000 \mathrm{U} / \mathrm{kg}$ Epo dose-treated group (Figure 4(b); $P=.03$ ). It is noteworthy, however, that despite the lack of statistical significance in the difference between Epo doses lower than $1000 \mathrm{U} / \mathrm{kg}$ compared to sham control, there is an overall trend of increasing physical activity with increasing Epo dose. This was also found to be the case for locomotor activity results as measured by total movement episodes per minute (episodes are separated by a rest period of at least 1 second; data not shown). Linear regression analysis for total physical activity of all mice on high fat diet receiving sham and Epo treatment $(0,150,300,600,1000 \mathrm{U} / \mathrm{kg})$ was also performed and showed that $R^{2}=0.3124$ (Figure 4(b) inset). Collectively, it was concluded that, at least for this study's period, Epo treatment causes detectable changes in physical activity only at $1000 \mathrm{U} / \mathrm{kg}$ dose, thereby suggesting that 


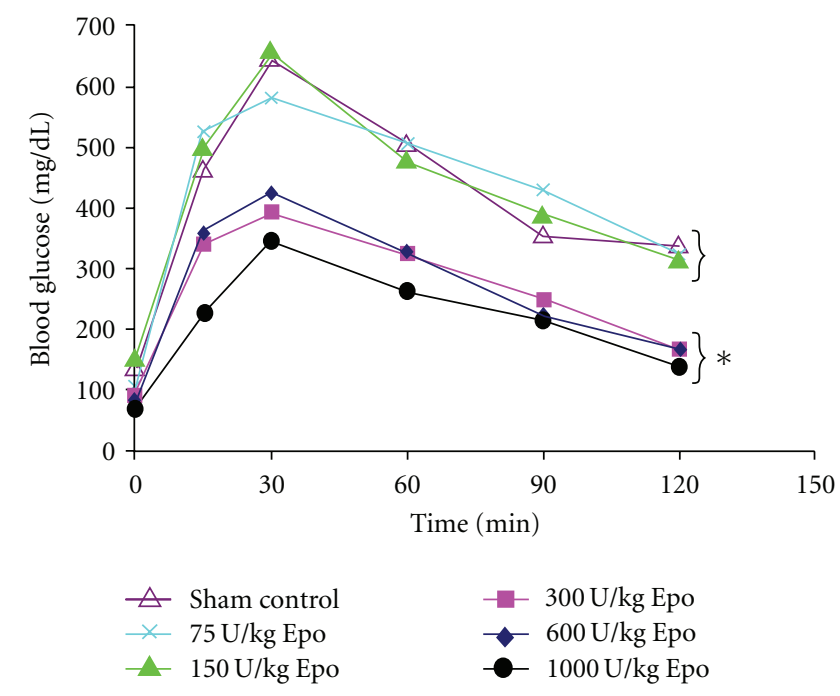

(a)

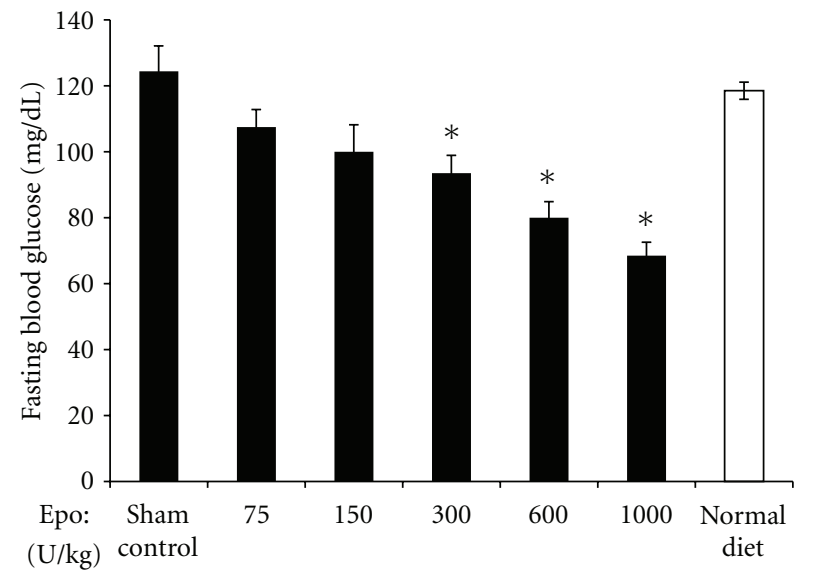

(b)

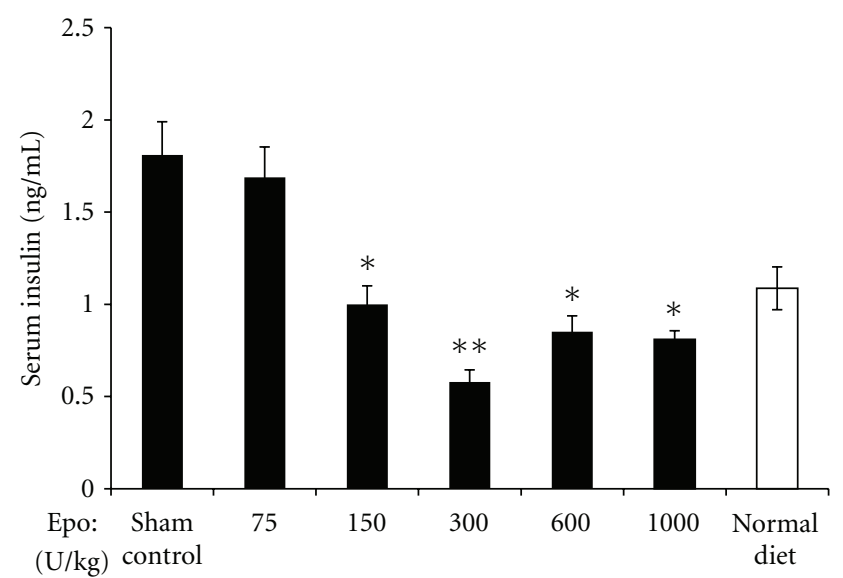

(c)

FIGURE 3: Epo-mediated improvement of glucose metabolism. C57BL/6 male mice ( 6 wks of age) were put on $60 \%$ high-fat diet and received exogenous Epo treatment of the following doses $(1000,600,300,150$, and $75 \mathrm{U} / \mathrm{kg})$ injected subcutaneously, three times a week; high-fat diet and control diet fed mice injected with saline only were used as sham and normal diet controls, respectively $(n=8$ mice/group). Glucose tolerance test (a) was performed at week 5 after study onset; all mice were fasted for 16 hours and challenged with an intraperitoneal load of glucose $(2 \mathrm{~g} / \mathrm{kg})$. Blood glucose was measured at $0,15,30,60,90$, and 120 minutes after glucose administration. The effects of different Epo dose treatments on fasting blood glucose (b) and serum insulin (c) were also assessed. The results are expressed as the mean \pm SEM. ANOVA single-factor test was used for statistical analysis; values of $P \leq .05$ were considered statistically significant.

changes in physical activity only partly explain the observed metabolic effects of Epo treatment. However, whether or not lower Epo doses $(600,300$, and $150 \mathrm{U} / \mathrm{kg})$ can also regulate body weight gain and fat mass by affecting physical activity, perhaps at levels below the detection threshold for the current technology, remains to be further investigated.

\section{Discussion}

High-fat diet-induced obesity mouse model is a wellcharacterized model that has been widely used to study diet-induced obesity and its associated insulin resistance $[2,18,19]$ and thus makes a suitable system to study the effects of exogenous Epo dose titration on body weight gain and glucose tolerance. Although, high-dose exogenous Epo treatment has been reported to reduce body weight and improve glucose tolerance, there is no information about the exact dose range of Epo treatment required for the reduced body weight gain, fat mass accumulation, and improved glucose tolerance. Moreover, it is still unclear whether such effects of Epo treatment are influenced by changes in food intake and/or physical activity. In this study, using highfat diet-induced obesity model, we report that Epo doses ranging from 300 to $1000 \mathrm{U} / \mathrm{kg}$ administered subcutaneously every $48 \mathrm{hrs}$ for a period of 5 weeks resulted in reduced body weight gain and fat mass, improved glucose tolerance, 


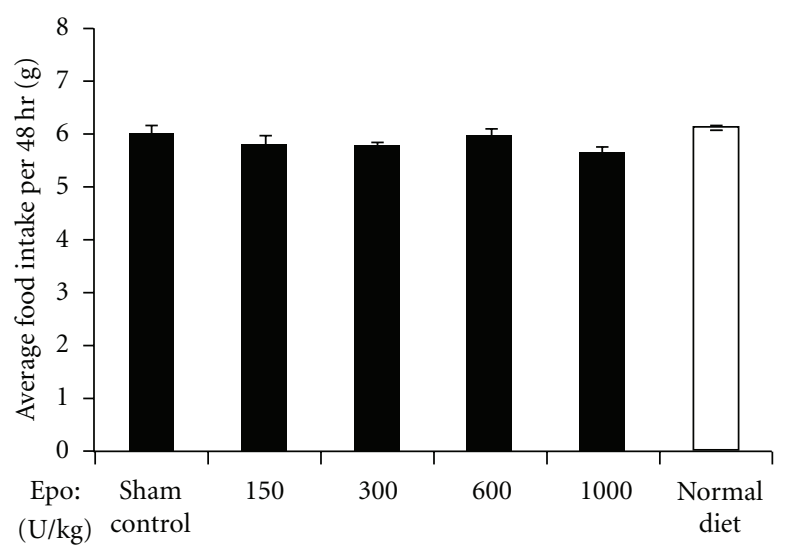

(a)

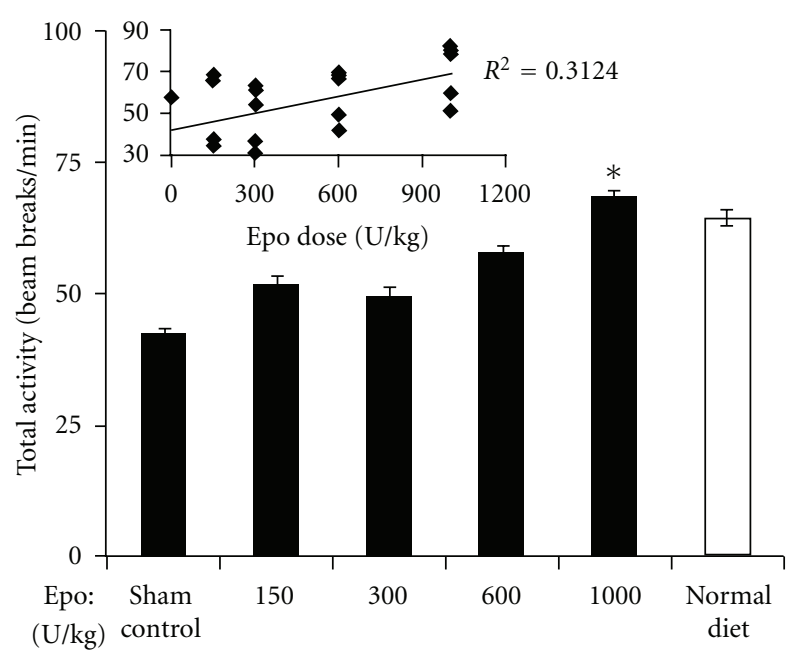

(b)

FIGURE 4: The effects of Epo treatment on food intake and physical activity. C57BL/6 male mice ( 6 wks of age) were put on $60 \%$ high-fat diet and received exogenous Epo treatment of the following doses $(1000,600,300,150$, and $75 \mathrm{U} / \mathrm{kg})$ injected subcutaneously, three times a week ( $n=6$ mice/group). After adapting to individual caging (i.e., one mouse per cage) for one week, the effects of Epo treatment on food intake (a) and physical activity (b) were determined for all groups and compared to lean and overweight mice injected with saline only as sham and normal diet controls, respectively. Results are expressed as the mean \pm SEM. ANOVA single-factor test was used for statistical analysis; values of $P \leq .05$ were considered statistically significant. Figure 4(b) inset summarizes the results of the linear regression analysis for total activity of all mice on high-fat diet receiving sham or Epo treatments $(0,150,300,600$, and $1000 \mathrm{U} / \mathrm{kg})$.

decreased serum insulin, and reduced fasting blood glucose (Figures 2 and 3). Lower Epo dose of $150 \mathrm{U} / \mathrm{kg}$ significantly reduced body weight gain and fat mass, and decreased serum insulin, with no detectable effects on fasting blood glucose or glucose tolerance, meanwhile $75 \mathrm{U} / \mathrm{kg}$ Epo dose did not show any change in these parameters (Figures 2 and 3 ).

Our findings with high-dose Epo $(1000 \mathrm{U} / \mathrm{kg})$ are in agreement with recent studies reporting reduction of body weight gain and blood glucose in a human Epo transgenic mouse model $(\operatorname{tg} 6)$, and as a result of very high-dose Epo treatment $(180 \mathrm{U} /$ mouse compared with $25 \mathrm{U} /$ mouse for high dose injection used here) using the leptin deficient $(\mathrm{ob} / \mathrm{ob})$ and tyrosine phosphatase $1 \mathrm{~B}$ deficient $\left(\mathrm{PTP} \mathrm{B}^{-/-}\right)$ mouse models of obesity and insulin resistance [19]. Our results are also consistent with recent reports showing that Epo expressed in supraphysiological levels has substantial metabolic effects including protection against diet-induced obesity, reduced serum insulin levels, and normalization of glucose sensitivity [18]. However, in addition to these reports, we show that high as well as medium (600 and $300 \mathrm{U} / \mathrm{kg})$ and low $(150 \mathrm{U} / \mathrm{kg})$ Epo doses can regulate body weight, fat mass, and certain aspects of glucose metabolism. Such distinction between high, medium, and low range of Epo doses becomes critical, when considering the adverse effects of high-Epo dose treatment reported in several clinical studies, leading to updated recommendations for Epo use in anemic cancer patients $[20,21]$.

To date, the exact mechanisms underlying Epo's action in regulating fat mass accumulation and glucose tolerance remain unknown. However, considering our observations showing that none of the Epo doses had any detectable effects on food intake, and only the $1000 \mathrm{U} / \mathrm{kg}$ dose significantly increased physical activity, these data suggest that food intake may not be involved while physical activity is only partially involved in Epo treatment-mediated regulation of body weight, fat mass, and glucose metabolism. To this end, it has been suggested that a shift to increased fat oxidation in muscle is responsible, at least in part, for the observed normalization of glucose sensitivity with high dose Epo [18]. Moreover, recent studies in our laboratory further suggest that Epo's ability to inhibit adipogenesis could be one mechanism through which it can regulate body weight and fat mass accumulation (Teng et al., unpublished data). It is also possible that Epo affects fat mass and glucose tolerance by directly regulating lipolysis, and insulin production and/or glucose utilization, or by indirect regulation of energy expenditure via affecting metabolic rates. Further studies to identify the exact molecular pathways underlying Epomediated regulation of fat mass and glucose metabolism are required.

It is intriguing that $300 \mathrm{U} / \mathrm{kg}$ Epo treatment resulted in a slightly more pronounced effect on body fat mass reduction and decreased serum insulin, with total activity levels statistically indistinguishable from the sham control, and slightly lower than those of the $1000 \mathrm{U} / \mathrm{kg}$ group (Figures 2(c), 3(c) and 4(b), resp.). A question raised here pertains to the possibility of an optimum effective dose for Epo $(300 \mathrm{U} / \mathrm{kg})$ in regulating fat mass and insulin levels. It is conceivable that such outcome may be due to the possible saturation of Epo receptor suggesting Epo response beyond hematopoietic tissue. Epo saturation has been previously reported to occur at high-Epo doses in nonerythroid culture 
systems [22]. Epo receptor is expressed at lower level in nonhematopoietic compared with erythroid progenitor cells, and hence, a higher level of Epo may be required for saturation of EpoR on erythroid progenitor cells. However, the applicability of such phenomenon to in vivo situations remains to be verified.

The link between cytokine signaling, body weight, and fat mass accumulation for other cytokines such as TNF- $\alpha$ and IL-18 on body weight and fat metabolism have been well documented. TNF- $\alpha$ also known as cachectin is known to promote lipolysis and inhibit the production of enzymes needed to produce and store fat $[23,24]$. IL-18 on the other hand has been shown to regulate energy homeostasis by suppressing apatite and feed efficiency and was strongly associated with obesity and insulin resistance, where IL18 deficient mice become obese and insulin resistant as a consequence of hyperphagia $[25,26]$. Most interestingly, the molecular mechanism identified to be responsible for IL18-mediated regulation of food intake and gluconeogenesis involves its ability to regulate STAT3 phosphorylation, where it was found that STAT3 phosphorylation can inhibit food intake and adipose tissue accumulation [25]. Considering the importance of STAT3 activation and phosphorylation during Epo signaling [27] and the observed effects of Epo signaling on body weight, fat mass, and glucose tolerance, it will be important to assess such effects for Epo signaling on apatite, body weight gain, fat mass accumulation, and glucose metabolism in mouse models with EpoR deficiency in nonhematopoietic tissues, and to investigate whether STAT3 activation and/or phosphorylation is responsible for the Epomediated regulation of the indicated metabolic parameters.

\section{Conclusion}

In summary, we report that high ( $1000 \mathrm{U} / \mathrm{kg})$, medium (600 and $300 \mathrm{U} / \mathrm{kg}$ ), and low (150 U/kg) doses of Epo are effective in reducing body weight and fat mass in mice on high fat diet. High and medium, but not low doses reduce fasting blood glucose and improve glucose tolerance, while all Epo doses, except $75 \mathrm{U} / \mathrm{kg}$, reduce serum insulin. These effects for Epo treatment do not appear to be mediated by regulating food intake. Moreover, since significant changes in total activity were only detected at $1000 \mathrm{U} / \mathrm{kg}$, it is suggested that physical activity is likely only partially responsible for the reported effects of Epo. Collectively, these observations indicate that the nonhematopoietic effects of Epo do indeed extend to encompass the regulation of fat and glucose metabolism and point to the possible involvement of pathways other than food intake and physical activity downstream of Epo.

\section{Acknowledgments}

The authors thank Oksana Gavrilova and the NIDDK Intramural Program Mouse Metabolism Core Facility for their excellent technical assistance in performing body composition analysis, serum insulin ELISA, and physical activity measurements. This work was supported by the Intramural Research Program of the National Institute of Diabetes and
Digestive and Kidney Diseases and the National Institutes of Health. Amanda Foskett and Mawadda Alnaeeli contributed equally to this work.

\section{References}

[1] D. Yach, D. Stuckler, and K. D. Brownell, "Epidemiologic and economic consequences of the global epidemics of obesity and diabetes," Nature Medicine, vol. 12, no. 1, pp. 62-66, 2006.

[2] G. S. Hotamisligil, "Inflammation and metabolic disorders," Nature, vol. 444, no. 7121, pp. 860-867, 2006.

[3] S. E. Shoelson, J. Lee, and A. B. Goldfine, "Inflammation and insulin resistance," Journal of Clinical Investigation, vol. 116, no. 7, pp. 1793-1801, 2006.

[4] S. Schenk, M. Saberi, and J. M. Olefsky, "Insulin sensitivity: modulation by nutrients and inflammation," Journal of Clinical Investigation, vol. 118, no. 9, pp. 2992-3002, 2008.

[5] V. Z. Rocha and P. Libby, "Obesity, inflammation, and atherosclerosis," Nature reviews. Cardiology, vol. 6, no. 6, pp. 399-409, 2009.

[6] L. A. Szczech, H. X. Barnhart, S. Sapp et al., "A secondary analysis of the CHOIR trial shows that comorbid conditions differentially affect outcomes during anemia treatment," Kidney International, vol. 77, no. 3, pp. 239-246, 2010.

[7] A. K. Singh, L. Szczech, K. L. Tang et al., "Correction of anemia with epoetin alfa in chronic kidney disease," The New England Journal of Medicine, vol. 355, no. 20, pp. 2085-2098, 2006.

[8] G. L. Semenza, S. T. Koury, M. K. Nejfelt, J. D. Gearhart, and S. E. Antonarakis, "Cell-type-specific and hypoxia-inducible expression of the human erythropoietin gene in transgenic mice," Proceedings of the National Academy of Sciences of the United States of America, vol. 88, no. 19, pp. 8725-8729, 1991.

[9] G. L. Semenza, "Involvement of oxygen-sensing pathways in physiologic and pathologic erythropoiesis," Blood, vol. 114, no. 10, pp. 2015-2019, 2009.

[10] E. B. Rankin, M. P. Biju, Q. Liu et al., "Hypoxia-inducible factor-2 (HIF-2) regulates hepatic erythropoietin in vivo," Journal of Clinical Investigation, vol. 117, no. 4, pp. 1068-1077, 2007.

[11] S. Pelletier, S. Gingras, M. Funakoshi-Tago, S. Howell, and J. N. Ihle, "Two domains of the erythropoietin receptor are sufficient for Jak2 binding/activation and function," Molecular and Cellular Biology, vol. 26, no. 22, pp. 8527-8538, 2006.

[12] N. Kertesz, J. Wu, T. H.-P. Chen, H. M. Sucov, and H. $\mathrm{Wu}$, "The role of erythropoietin in regulating angiogenesis," Developmental Biology, vol. 276, no. 1, pp. 101-110, 2004.

[13] H. Wu, S. H. Lee, J. Gao, X. Liu, and M. L. Iruela-Arispe, "Inactivation of erythropoietin leads to defects in cardiac morphogenesis," Development, vol. 126, no. 16, pp. 35973605, 1999.

[14] X. Yu, J. J. Shacka, J. B. Eells et al., "Erythropoietin receptor signalling is required for normal brain development," Development, vol. 129, no. 2, pp. 505-516, 2002.

[15] C. J. Parsa, A. Matsumoto, J. Kim et al., "A novel protective effect of erythropoietin in the infarcted heart," Journal of Clinical Investigation, vol. 112, no. 7, pp. 999-1007, 2003.

[16] M. Sakanaka, T. C. Wen, S. Matsuda et al., "In vivo evidence that erythropoietin protects neurons from ischemic damage," Proceedings of the National Academy of Sciences of the United States of America, vol. 95, no. 8, pp. 4635-4640, 1998.

[17] M. Bernaudin, H. H. Marti, S. Roussel et al., "A potential role for erythropoietin in focal permanent cerebral ischemia 
in mice," Journal of Cerebral Blood Flow and Metabolism, vol. 19, no. 6, pp. 643-651, 1999.

[18] P. Hojman, C. Brolin, H. Gissel et al., "Erythropoietin overexpression protects against diet-induced obesity in mice through increased fat oxidation in muscles," PLoS One, vol. 4, no. 6, Article ID e5894, 2009.

[19] O. Katz, M. Stuible, N. Golishevski et al., "Erythropoietin treatment leads to reduced blood glucose levels and body mass: insights from murine models," Journal of Endocrinology, vol. 205, no. 1, pp. 87-95, 2010.

[20] J. R. Wright, Y. C. Ung, J. A. Julian et al., "Randomized, double-blind, placebo-controlled trial of erythropoietin in non-small-cell lung cancer with disease-related anemia," Journal of Clinical Oncology, vol. 25, no. 9, pp. 1027-1032, 2007.

[21] J. D. Rizzo, M. Brouwers, P. Hurley et al., "American Society of Hematology/American Society of Clinical Oncology clinical practice guideline update on the use of epoetin and darbepoetin in adult patients with cancer," Blood, vol. 116, no. 20, pp. 4045-4059, 2010.

[22] M. Ogilvie, X. Yu, V. Nicolas-Metral et al., "Erythropoietin stimulates proliferation and interferes with differentiation of myoblasts," Journal of Biological Chemistry, vol. 275, no. 50, pp. 39754-39761, 2000.

[23] T. Petruschke and H. Hauner, "Tumor necrosis factor- $\alpha$ prevents the differentiation of human adipocyte precursor cells and causes delipidation of newly developed fat cells," Journal of Clinical Endocrinology and Metabolism, vol. 76, no. 3, pp. 742-747, 1993.

[24] X. Chen, K. Xun, L. Chen, and Y. Wang, "TNF- $\alpha$, a potent lipid metabolism regulator," Cell Biochemistry and Function, vol. 27, no. 7, pp. 407-416, 2009.

[25] M. G. Netea, L. A. B. Joosten, E. Lewis et al., "Deficiency of interleukin-18 in mice leads to hyperphagia, obesity and insulin resistance," Nature Medicine, vol. 12, no. 6, pp. 650 656, 2006.

[26] E. P. Zorrilla, M. Sanchez-Alavez, S. Sugama et al., "Interleukin-18 controls energy homeostasis by suppressing appetite and feed efficiency," Proceedings of the National Academy of Sciences of the United States of America, vol. 104, no. 26, pp. 11097-11102, 2007.

[27] N. Seubert, Y. Royer, J. Staerk et al., "Active and inactive orientations of the transmembrane and cytosolic domains of the erythropoietin receptor dimer," Molecular Cell, vol. 12, no. 5, pp. 1239-1250, 2003. 


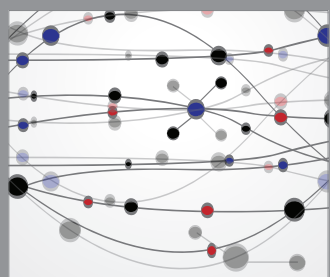

The Scientific World Journal
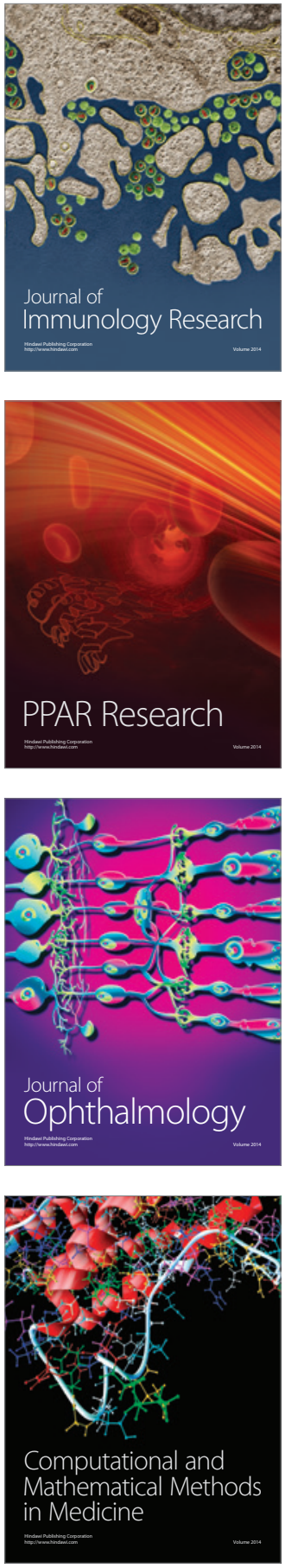

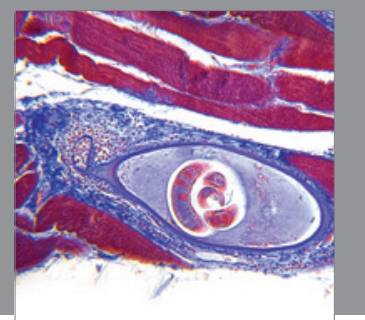

Gastroenterology

Research and Practice
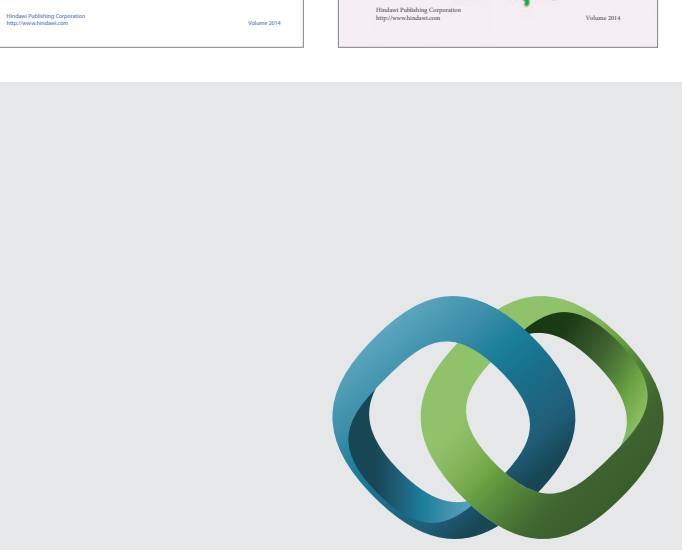

\section{Hindawi}

Submit your manuscripts at

http://www.hindawi.com
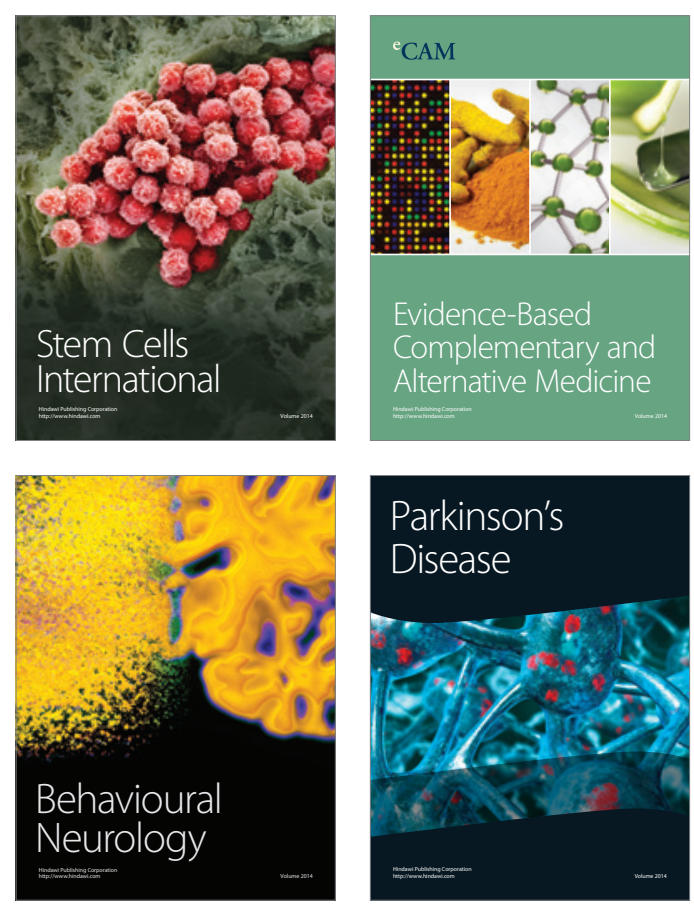

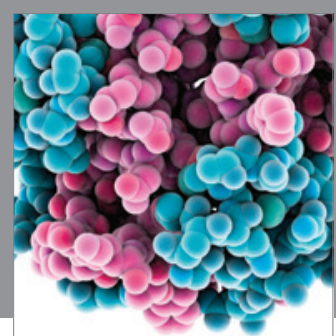

Journal of
Diabetes Research

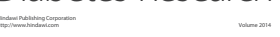

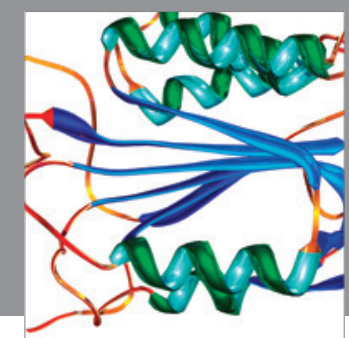

Disease Markers
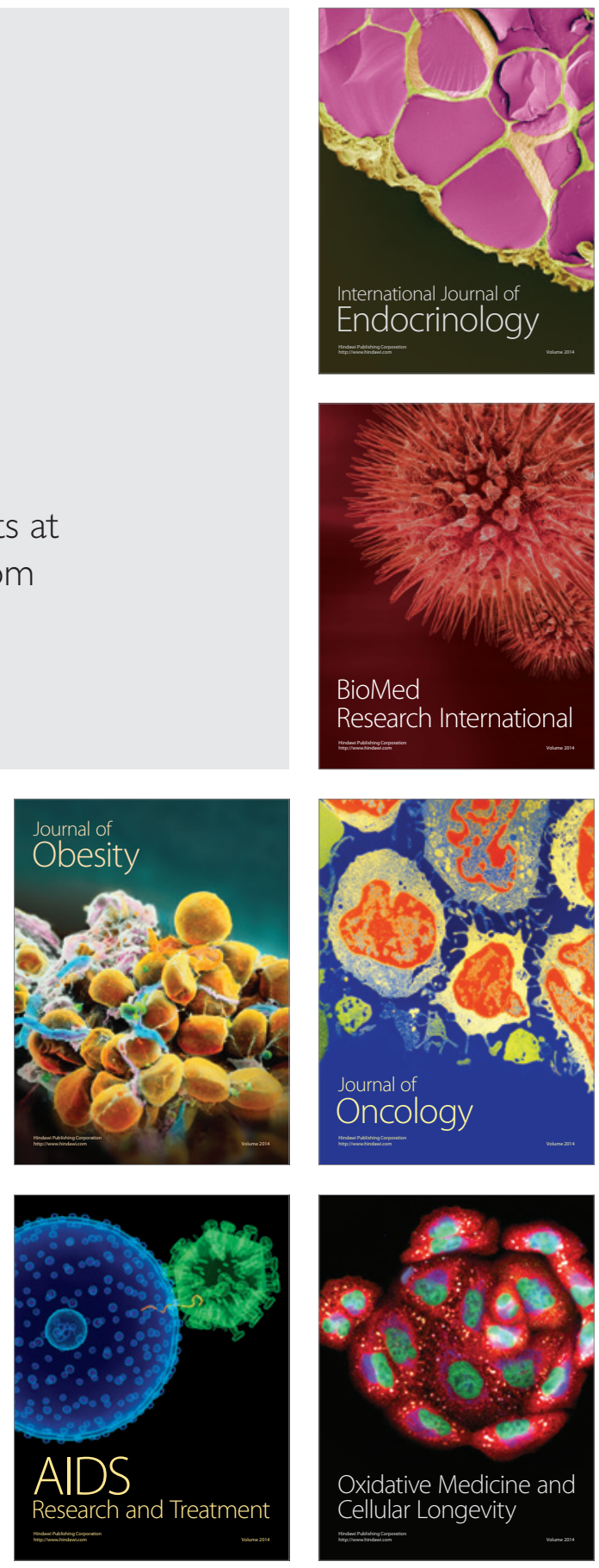